OPEN ACCESS

Edited by:

Manuela Viola

University of Insubria, Italy

Reviewed by:

Cinzia Cocola,

Italian National Research Council, Italy

Hiroshi Kitagawa,

Kobe Pharmaceutical University,

Japan

*Correspondence:

Yin Shi

flysy0636@163.com

Luyi Wu

luyitcm@163.com

${ }^{+}$These authors have contributed equally to this work and share first

authorship

Specialty section:

This article was submitted to

Molecular and Cellular Oncology,

a section of the journal

Frontiers in Cell and Developmental

Biology

Received: 28 September 2021

Accepted: 03 December 2021

Published: 18 January 2022

Citation:

Guo S, WuX, Lei T, Zhong R, Wang $Y$, Zhang L, Zhao Q, Huang $Y$, Shi $Y$ and Wu L (2022) The Role and Therapeutic

Value of Syndecan-1 in Cancer

Metastasis and Drug Resistance.

Front. Cell Dev. Biol. 9:784983.

doi: 10.3389/fcell.2021.784983

\section{The Role and Therapeutic Value of Syndecan-1 in Cancer Metastasis and Drug Resistance}

\author{
Sen Guo ${ }^{1+}$, XinYi Wu ${ }^{1+}$, Ting Lei ${ }^{1+}$, Rui Zhong ${ }^{1}$, YiRan Wang ${ }^{1}$, Liang Zhang ${ }^{1}$, QingYi Zhao ${ }^{1}$, \\ Yan Huang ${ }^{2}$, Yin Shi ${ }^{3,4 *}$ and Luyi $\mathrm{Wu}^{2 *}$ \\ ${ }^{1}$ Shanghai University of Traditional Chinese Medicine, Shanghai, China, ${ }^{2}$ Key Laboratory of Acupuncture and Immunological \\ Effects, Shanghai Research Institute of Acupuncture and Meridian, Shanghai, China, ${ }^{3}$ Department of Acupuncture and \\ Moxibustion, Yueyang Hospital of Integrated Traditional Chinese and Western Medicine Affiliated to Shanghai University of \\ Traditional Chinese Medicine, Shanghai, China, ${ }^{4}$ Outpatient Department, Shanghai Research Institute of Acupuncture and \\ Meridian, Shanghai, China
}

Metastasis and relapse are major causes of cancer-related fatalities. The elucidation of relevant pathomechanisms and adoption of appropriate countermeasures are thus crucial for the development of clinical strategies that inhibit malignancy progression as well as metastasis. An integral component of the extracellular matrix, the type 1 transmembrane glycoprotein syndecan-1 (SDC-1) binds cytokines and growth factors involved in tumor microenvironment modulation. Alterations in its localization have been implicated in both cancer metastasis and drug resistance. In this review, available data regarding the structural characteristics, shedding process, and nuclear translocation of SDC-1 are detailed with the aim of highlighting strategies directly targeting SDC-1 as well as SDC-1-mediated carcinogenesis.

Keywords: syndecan-1, metastasis, drug resistance, therapy, cancer

\section{INTRODUCTION}

Cell surface proteoglycans are responsible for many aspects of cellular behavior. The four-member syndecan (SDC) family of heparan sulfate proteoglycans includes SDC-1 (CD138), 2, 3 and 4 (Rhodes and Simons, 2007; Couchman, 2010). Expressed primarily on the surface of epithelial and plasma cells, SDC-1 has been the most intensively studied of the four (Saunders et al., 1989). A key cell surface adhesion molecule, SDC-1 contains heparan sulfate (HS) chains which interact with a large number of molecules crucial in the maintenance of cell morphology and intercellular signaling such as extracellular matrix components, growth factors and integrins. Dysregulation of SDC-1 may promotes carcinogenesis, cancer recurrence and resistance to chemotherapy. Expression of SDC-1 may thus serve as a potential marker to identify patients predisposed to drug-resistant disease or metastasis on initial cancer diagnosis. As the membrane-anchored SDC-1 undergoes both nuclear translocation as well as extracellular shedding, emerging studies have focused on location-specific roles played by this protein in tumor pathology.

Although data detailing the relationship between tumor progression and changes in the location of SDC-1 expression are scarce, analysis of available literature would nevertheless further understanding of molecular events associated with variations in SDC-1 localization. Here, we review the positional variability of this proteoglycan, how tissue-specific metastasis, in turn, is affected, as well as relevant influences on tumor resistance to treatment. In addition, we provide an evidence-based foundation for the development of potential clinical management strategies targeting SDC-1 in the setting of malignancy. 


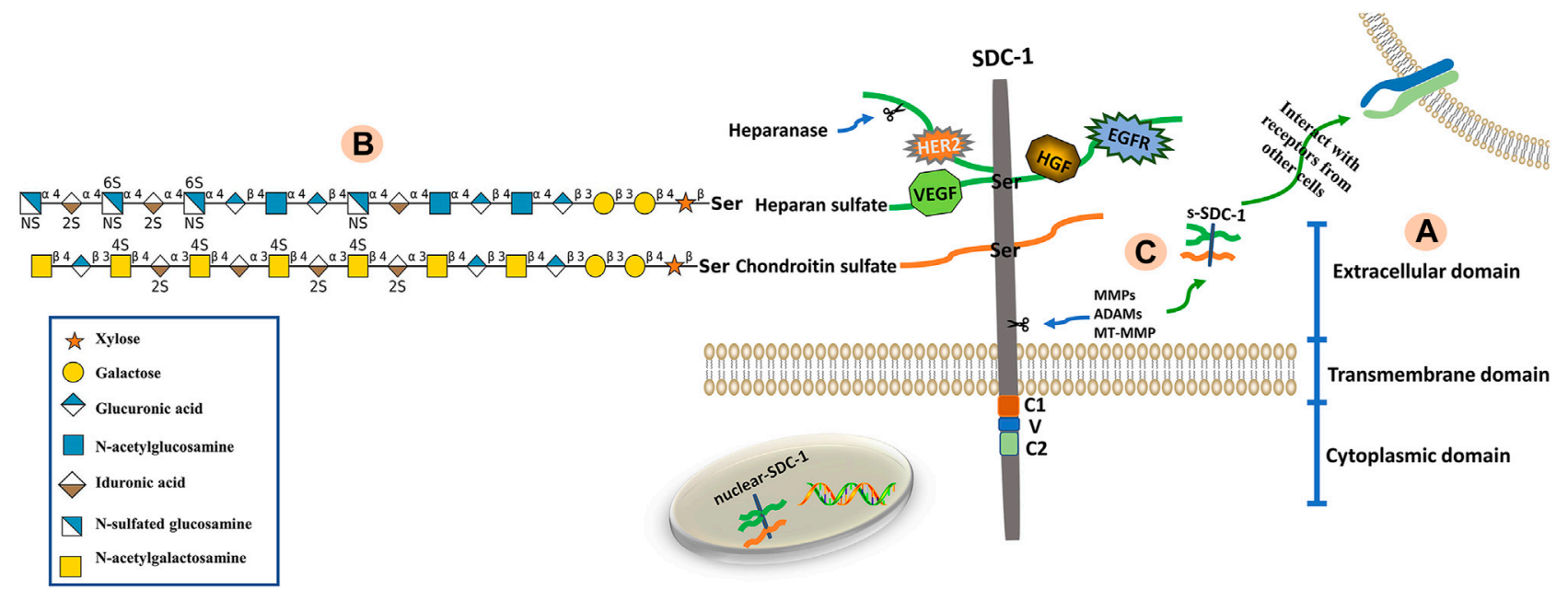

FIGURE 1|Structure of SDC-1. (A) The SDC-1 core protein consists of three major (extracellular, transmembrane and cytoplasmic) domains. (B) The extracellular domain is bound via glycosaminoglycan (heparan sulfate, HS; chondroitin sulfate, CS) chains. The HS and CS chains are composed of repeating disaccharide units (glycan structures are represented according to the Symbol Nomenclature for Glycans (SNFG) (Cheng et al., 2017)) linked to core protein serine residues. Growth factors and receptors (e.g., HER2, VEGF, HGF and EGFR) bind to HS chains, which can be fragmented by heparanase. (C) The extracellular domain of SDC-1 is cleaved by sheddases (e.g., MMPs, ADAMs, MT-MMP), a phenomenon known as shedding. This results in the release of attached glycosaminoglycan chains as well as any bound ligands from the cell surface into the extracellular environment.

\section{STRUCTURAL AND BIOCHEMICAL CHARACTERISTICS OF SDC-1}

Syndecans are heparan sulfate proteoglycans with core proteins possessing heparan sulfate chains. The SDC-1 core protein can also be modified by chondroitin sulfate (CS) chains (Jenkins et al., 2018). The core proteins of syndecans are composed of three domains; namely extracellular (ectodomain, ED), transmembrane (TMD) and cytoplasmic (CD) domains (Bernfield et al., 1999). The short, highly-conserved CD can be further divided into conserved C1 (membrane-proximal) and C2 (membrane-distal) regions that flank a $\mathrm{V}$ region. The $\mathrm{V}$ region sequence is distinct among each of the four syndecan family member proteins and likely confers unique functional characteristics (Tkachenko et al., 2005; De Rossi and Whiteford, 2013). The C1 region interacts with actin-bound proteins and participates in endocytosis, while the $\mathrm{C} 2$ region interacts with a variety of PDZ proteins, such as syntenin, and thus functions in exosome formation and cytoplasmic trafficking (Das et al., 2003; Maday et al., 2008; Jung et al., 2016). The V region is critical for lamellipodial extension, actin bundling and cell migration (Chakravarti et al., 2005). Maintenance of the actin cytoskeleton and membrane trafficking are primarily regulated by the CD (Alexopoulou et al., 2007). The ED is composed of two or three consecutive Ser-Gly sequences surrounded by hydrophobic and acidic residues that serve as HS or CS attachment sites (Bourdon et al., 1987). The HS chains consist of unbranched, repeating disaccharide units of either glucuronic (GlcUA) or iduronic (IdoA) acid alternating with unsubstituted or $\mathrm{N}$-substituted glucosamine, on which the substituents are either acetate (GlcNAc; N-acetylglucosamine) or sulfate (GlcNS; N-sulfated glucosamine) (Zhang et al., 1995; Park,
2016). The CS chains, which are closer to the membrane surface are synthesized onto a linkage tetrasaccharide (GlcUAGal-Gal-Xyl), covalently bound to core protein serine residues via the alternating addition of GalNAc and GlcUA units by CS synthases (Ogawa et al., 2010). A defining characteristic of these polysaccharides is the presence of sulfate and uronic acid residues, which endow them with significant anionic properties. As such, numerous proteins containing basic amino acid clusters are capable of interacting with HS chains (Mulloy et al., 2017). Sulfatases such as Sulf1 and Sulf2 change the affinity of HSbinding ligands by removing 6-O-sulfate groups from $\mathrm{HS}$ chains (El Masri et al., 2020). The structural composition of SDC-1 is shown in Figure 1.

\section{TRANSLOCATION OF SDC-1}

Changes in SDC-1 location uniquely impact cellular function and encompass anchoring to the cell membrane, ED shedding or nuclear translocation.

\section{Shedding of the SDC-1 Ectodomain}

Syndecans bound to the cell surface act as multifunctional modulators of signaling. As such, proteolytic shedding of the $\mathrm{ED}$, which converts membrane-bound SDC-1 into a shed form, significantly affects signaling functions. Shed SDC-1 retains its HS chains along with bound ligands that endow it with the capacity to act in paracrine or autocrine manners as well as functionality as a competitive inhibitor (Bertrand and Bollmann, 2019). Cell surface receptor dynamics are thus regulated by ED shedding, which results in competition for ligands in the pericellular environment by intact syndecans and potentially 
eliminates their co-receptor role in various signaling pathways (Piperigkou et al., 2016). Various metalloproteinases including matrix metalloproteinases (MMPs), membrane type MMPs (MTMMP) and a disintegrin and metalloproteinase with thrombospondin motifs (ADAMTS) are responsible for cleaving SDC-1 from the cell surface (Bode and Maskos, 2003; Gomis-Rüth, 2009; Hadigal et al., 2020). In addition to HS chain cleavage, heparanase promotes SDC-1 shedding via the regulation of MMP-9 and urokinase-type plasminogen activator expression (Ramani et al., 2016). The cleavage of HS chains by heparanase not only accelerates the shedding process by providing sheddases access to the SDC-1 core protein, but also allows the extracellular binding of growth factors to the cleaved chains to disseminate across a long distance (Matsuo and Kimura-Yoshida, 2013; Rangarajan et al., 2020). In the conserved CD regions, tyrosine phosphorylation likewise results in ED shedding (Manon-Jensen et al., 2010). Shed SDC-1 proceeds to mediate extracellular signaling in an environment-dependent manner.

\section{Nuclear Translocation of SDC-1}

Intranuclear SDC-1 has been detected in the setting of multiple myeloma (Stewart et al., 2015), prostate cancer (Farfán et al., 2020) and mesothelioma (Kumar-Singh et al., 2020). Colocalization of SDC-1 with tubulin in the mitotic spindle further confirmed this phenomenon (Zong et al., 2009; Szatmári et al., 2017). Nuclear import of protein requires its targeting by nuclear localization signal (NLS) short peptide sequences (Duverger et al., 1995). The minimal sequence required for the tubulin-dependent nuclear translocation of SDC-1 is considered to be the conserved juxtamembrane RMKKK motif present in its CD (Zong et al., 2009; Zong et al., 2010; Zong et al., 2011). Shed SDC-1 has recently been reported to undergo nuclear translocation in both tumor and bone marrow stromal cells, with the presence of HS chains required for this process (Stewart et al., 2015). Intracellular signaling can be altered by the presence of intranuclear SDC-1 via protein phosphorylation and post-translational modification. The majority of intranuclear SDC-1 was detected in discrete patches within euchromatin, indicating specific localization to regions of active gene transcription. In the human myeloma cell, intranuclear SDC-1 interacts with the enzyme histone acetyltransferase p300 (HAT) via HS chains to decrease its activity and thus histone acetylation (Purushothaman et al., 2011). In aggressive myeloma cells, heparanase mediates the loss of nuclear SDC-1, enhancing HAT activity and resulting in upregulated vascular endothelial growth factor (VEGF) and matrix metalloproteinase-9 (MMP-9) expression (Szatmári et al., 2017; Amin et al., 2020). In addition to mediating the nuclear translocation of SDC-1 and histone $\mathrm{H} 3$ acetylation, HS chains that enter the nucleus play important roles in cell signaling. Intranuclear HS chains control transcription by inhibiting DNA topoisomerase; this prevents DNA relaxation and the binding of transcription factors (Kovalszky et al., 1998). Direct inhibition of transcription factors by intranuclear HS chains likely occurs due to their DNA-binding domains containing sequences with a highaffinity for heparan (Dudás et al., 2000; Stewart and Sanderson,
2014). Furthermore, HS can transport heparan-binding growth factors such as hepatocyte growth factor (HGF) and fibroblast growth factor 2 (FGF2) into the nucleus via internalization. Adherence to HS chains by ligands, pathogens, peptides and exosomes can also lead to their nuclear importation (Christianson and Belting, 2014). Consequently, cancer cell pathophysiology including tumor growth, metastasis and angiogenesis is uniquely affected by whether SDC-1 is membrane-bound, shed or transported to the cell nucleus.

\section{PROMOTION OF METASTASIS BY SDC-1}

Cancer cell metastasis is generally divided into five stages: local invasion, intravasation, circulatory system survival, extravasation and colonization. Cellular migration entails loss of focal cellular adhesion, decrease in adherence to cell substrates, formation of new adhesions, and finally, polymerization and depolymerization of the actin cytoskeleton (Mythreye and Blobe, 2009). The precise mechanisms of relevant signal transduction to target cells, however, remain unknown. Due to the variability of the SDC-1 domain, changes in its location have been speculated to correlate with the occurrence of metastasis. Highly expressed on epithelial cells, the heparan-binding domains of SDC-1 are capable of binding laminin, collagen, fibronectin and thrombospondin, resulting in activation of focal adhesion kinase (FAK) signaling. Cell-tosubstrate adhesion via SDC-1 binding the laminin $\alpha$ chain is also facilitated (Salmivirta et al., 1994; Hoffman et al., 1998; Chakravarti et al., 2005; Ogawa et al., 2007). Moreover, fluorescence recovery after photobleaching studies have revealed the TMD to control cell motility and thus adhesion complex protein cycling as well as focal adhesion turnover modulation (Altemeier et al., 2012a). The degradation of extracellular substrates by MT1-MMP as well as its activation of pro-MMP-2 and pro-MMP-13 effectively stimulates matrix turnover and significantly influences malignant metastasis (Ingvarsen et al., 2020). In colorectal carcinoma cells, SDC-1 expression was reported to reduce MMP-9 levels, impede invasion into type I collagen and promote cell adhesion by boosting intercellular cell adhesion molecule-1 (ICAM-1) expression (Wang et al., 2019). Heparanase, however, promotes SDC-1 shedding, which is accompanied by upregulated MMP levels and increased metastasis (Ramani et al., 2016). In addition, SDC-1 regulates focal adhesion dynamics via control of Rap1 (a small GTPase that switches integrins to a high-affinity state) to slow cell disadhesion and suppress migration (Boettner and Van Aelst, 2009; Altemeier et al., 2012b). In the setting of various malignancies, expression of the chaperone protein Hsp90 on the cell surface is often upregulated (Birbo et al., 2021). Of note, Hsp90 was found to play a role in tumor cell invasion and metastasis by promoting EGFR3/HER2 dimerization and EGFR signaling (Sidera et al., 2008), thus increasing both MMP and extracellular matrix protein stability and activity (Correia et al., 2013). Extracellular Hsp90 can be bound by HS chains to induce human glioblastoma A-172 and fibrosarcoma HT1080 cell metastasis (Snigireva et al., 2019). In breast cancer (Nadanaka et al., 2021), multiple myeloma (Purushothaman and Sanderson, 2020) and pancreatic cancer (Chen et al., 2020), greater SDC-1 shedding was similarly found 


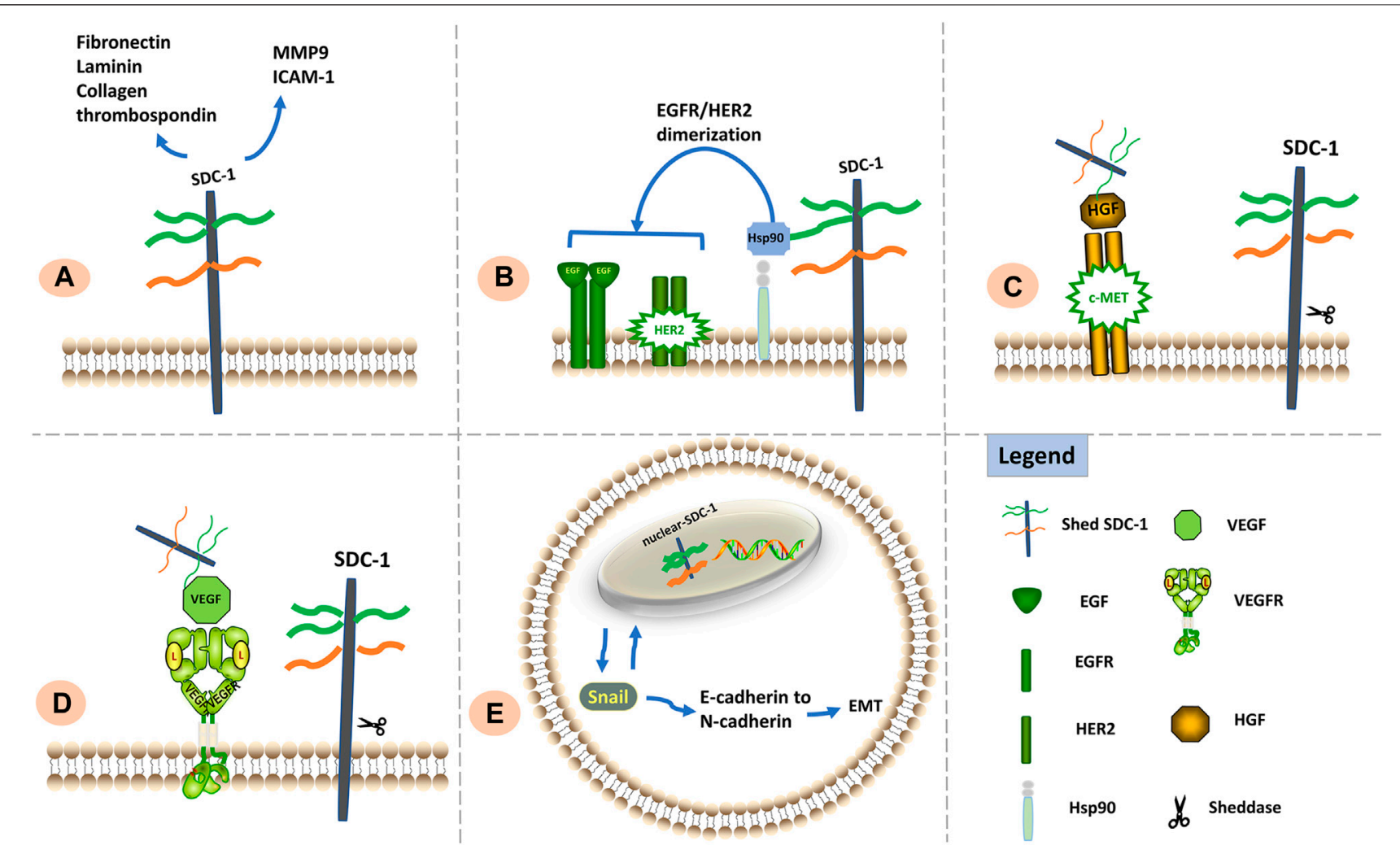

FIGURE 2| Signaling functions of SDC-1 relevant to cell metastasis and invasion. (A) SDC-1 interacts with a vast number of extracellular matrix molecules such as MMP9, ICAM1, fibronectin, laminin, thrombospondin, and collagen; such interactions are facilitated via multivalent binding of these molecules to HS chains, thereby influencing cellular adhesive properties. (B) The HS chains of SDC-1 can bind extracellular Hsp90 to promote EGFR/HER2 dimerization and induce metastasis. (C). Shed SDC-1/HGF complex stimulates cell migration via the c-Met receptor. (D). Shed SDC-1 binds VEGF to promote endothelial cell invasion. (E). Nuclear translocation of SDC-1 modulates the EMT via interaction with Snail, resulting in enhanced tumor cell invasiveness.

to associate with increased metastasis, indicating that shed SDC-1 likely serves as a major facilitator for malignant cellular invasion. Shed SDC-1 may promotes metastasis and invasion via growth factors linked to its HS chains. Meanwhile, c-Met, a protein that possesses tyrosine kinase activity, mediates mesenchymal-epithelial interactions (Birchmeier et al., 2003; Nakamura et al., 2011). In myeloma cells, HGF binds to cell surface-bound SDC-1 with the resultant SDC-1/HGF complex stimulating cell migration via the c-Met receptor upon SDC-1 cleavage (Ramani et al., 2011). Shed SDC-1 binds VEGF, anchoring it close to the matrix and further promoting endothelial cell invasion (Purushothaman et al., 2010).

Epithelial cells on the invasive front typically acquire migratory and invasive capabilities by overcoming physical barriers during the epithelial-mesenchymal transition (EMT). Nuclear translocation of SDC-1 further enhances its modulation of the EMT as well as tumor invasiveness. Cadherin (isoform) switching is an EMT characteristic and has been linked to the development of invasive and metastatic features in epithelial malignancies (Loh et al., 2019). A positive correlation between Snail expression and nuclear SDC-1 translocation was reported in prostate cancer cells (Farfán et al., 2020); cells overexpressing Snail exhibited increased nuclear SDC-1 levels in comparison with cytoplasmic concentrations (Millanes-Romero et al., 2013). The nuclear translocation of SDC-1, however, was also reported to facilitate elimination of mesenchymal and invasive characteristics among human B6FS fibrosarcoma cells, with loss of nuclear SDC-1 related to cell elongation and E- to $\mathrm{N}$-cadherin switching during the TGF- $\beta 1$-induced EMT in human A549 lung cancer cells (Kumar-Singh et al., 2021). The influence of intranuclear SDC-1 thus likely differs between different tumors and further study is required to elucidate how nuclear SDC-1 controls the EMT.

Effects of SDC-1 differ according to its location: the ED is crucial for maintaining cell adhesion whereas the TMD and CD are important for inhibiting cell migration; cell adhesion and migration capabilities also appear to be influenced by the intranuclear presence of SDC-1 (Zong et al., 2011). Signaling functions of SDC-1 relevant to metastasis and invasion are shown in Figure 2.

\section{IMPACT OF SDC-1 ON CANCER RESISTANCE TO THERAPY}

Shed SDC-1, along with factors that bind to its HS chains, facilitates establishment of a tumor microenvironment that promotes disease recurrence and robust growth via the 
enhancement of growth factor signaling in host cells. As such, it is hypothesized that radiotherapy or chemotherapy may indeed increase extracellular SDC-1 deposition, subsequently leading to tumor recurrence and metastasis (Masola et al., 2014; Bandari et al., 2018).

Treatment with doxorubicin, dexamethasone, cisplatin and carfilzomib was found to significantly increase levels of shed SDC-1 lacking the CD (Ramani and Sanderson, 2014). Furthermore, chemotherapy was found to potentially promote HGF/c-Met/IL-11 activation via SDC-1 shedding, exacerbating bone destruction in the setting of myeloma (Ramani et al., 2011). Shed SDC-1 was also reported to promote VEGF signaling, thus increasing the rate of angiogenesis (Jung et al., 2016; Javadi et al., 2020). The HS chains of shed and full-length SDC-1 compete to bind downstream epithelial growth factor receptor (EGFR), subsequently facilitating resistance to chemotherapy in colorectal cancer cells (Wang et al., 2014). Interestingly, higher levels of shed SDC-1 were found to associate with chemoresistance; chemoresistant cells both expressed higher levels of SDC-1 mRNA and, in turn, produced more of the protein (Ramani and Sanderson, 2014). Greater levels of SDC-1 were also found to correlate with reduced responsiveness to cyclophosphamide and epirubicine therapy in cells obtained from pre-chemotherapy biopsies of breast cancer tissue (Götte et al., 2006).

Phosphatidylinositol 3-kinase (PI3K) is a lipid kinase that regulates a variety of cellular processes, while protein kinase $\mathrm{B}$ (AKT) is a major downstream effector of PI3K signaling that modulates pathways critical for the inhibition of apoptosis, stimulation of cell growth and modulation of cellular metabolism; aberrant PI3K/AKT activation is thus considered to be as among the significant cause of chemoresistance (Liu et al., 2020). Membrane expression of SDC-1 has likewise been linked to increased chemoresistance in hepatic carcinoma cells via PI3K/ AKT pathway changes (Yu et al., 2020). Considering that shed SDC-1 promotes the EMT, high levels of shed SDC-1 were found to upregulate expression of EMT-TFs including ZEB1, Snaill and Snail2 in breast and pancreatic cancer models to induce expression of the stemness factors SOX2, BMI1, and OCT4, thus facilitating chemoresistance (Pradella et al., 2017).

Heparanase upregulation in the setting of anti-myeloma therapy may serve as markers of chemoresistance and eventual relapse. Heparanase was found present within autophagosomes and chemoresistance triggered by heparanase was reported to be partly mediated by enhanced autophagy (Shteingauz et al., 2015). In addition, while increased heparanase activity was reported in lapatinib-resistant HER2 and EGFR-positive breast cancer cells, heparanase inhibition was found to re-sensitize these cells to lapatinib (Zhang et al., 2015).

Exosomes transport proteins, mRNA and miRNA between tumor and host cells; their role in the intercellular shuttling of drug-resistant contents has recently garnered attention (Chen et al., 2014). The SDC-1 CD interacts with syntenin and ALIX to generate a complex that allows intraluminal vesicles to emerge within endosomal membranes, thus contributing to the formation of exosomes (Roucourt et al., 2015). Myeloma cells exposed to elevated heparanase levels exhibited increased secretion of exosomes containing SDC-1 and heparanase (Bandari et al.,
2018). As both SDC-1 and heparanase possess tumorigenic properties, exosomes containing them significantly alter both the local microenvironment as well as distant cell functions.

After malignant cells achieve target organ infiltration, they proceed to adapt to their new microenvironment. Tumor cells lacking appropriate signaling functionality either become unable to grow or enter a relatively dormant state (Pantel and Brakenhoff, 2004). Among malignant cells that enter such a quiescent state, metastatic breast cancer cells were noted to escape dormancy after vascular cell adhesion molecule1(VCAM-1) upregulation. Abnormal VCAM-1 expression was found to induce disseminated tumor cell binding to osteoclasts expressing the $\alpha 4 \beta 1$ integrin, resulting in bone metastasis ( $\mathrm{Lu}$ et al., 2011). Considering that shed SDC-1 increases VCAM-1 expression, shed SDC-1 delivered from distant tumor microenvironments similarly promotes growth in otherwise dormant cancer cells and thus facilitates disease relapse and metastasis (de Oliveira Neves et al., 2019).

Combined clinical application of MMP inhibitors for the purpose of impeding SDC-1 shedding along with chemotherapy may offer a unique approach aimed at preventing formation of microenvironments conducive to tumor recurrence. Significant signaling functions of SDC-1 in chemoresistance are shown in Figure 3.

\section{PERSPECTIVES FOR THERAPEUTIC INTERVENTION TARGETING SDC-1}

Due to its multiple roles in cancer pathophysiology, SDC-1 is an appealing molecular target for therapeutic strategies. In this section, we summarize progress made regarding the targeting of SDC-1 for therapeutic purposes in the setting of malignancy.

\section{Targeting of SDC-1}

Interaction between SDC-1 and the extracellular matrix plays an essential role in cancer pathogenesis. Treatment with zoledronate significantly downregulates the expression of SDC-1 and integrins $\alpha v \beta 3$, $\alpha v \beta 5$ and $\alpha 5 \beta 1$; this medication is thus considered to be a powerful anti-cancer agent particularly useful for the inhibition of breast cancer cell proliferation, migration and matrix invasion (Dedes et al., 2012). Nimesulide, a non-steroidal anti-inflammatory drug (COX-2 specific inhibitor), blocks the tumorigenic activities of SDC-1 in the setting of primary effusion lymphoma (George Paul et al., 2011). Indatuximab ravtansine (BT062), a monoclonal antibody connected to the cytotoxic agent DM4 (ravtansine), specifically targets cells expressing SDC-1. When absorbed by target cells, the highly-specific DM4 produces cytotoxic effects with minimal systemic toxicity (Schönfeld et al., 2017; Jagannath et al., 2019).

A number of cellular pathways are potential targets for the inhibition of carcinogenic effects exerted by SDC-1. The completely humanized SDC- 1 recombinant antibody OC-46F2 reduces SDC-1/VEGFR-2 activity in tumor microenvironments, consequently blocking vascular maturation and tumor growth in the setting of malignant melanoma and experimental models of ovarian cancer (Orecchia et al., 2013). The aVB3-SDC-1 


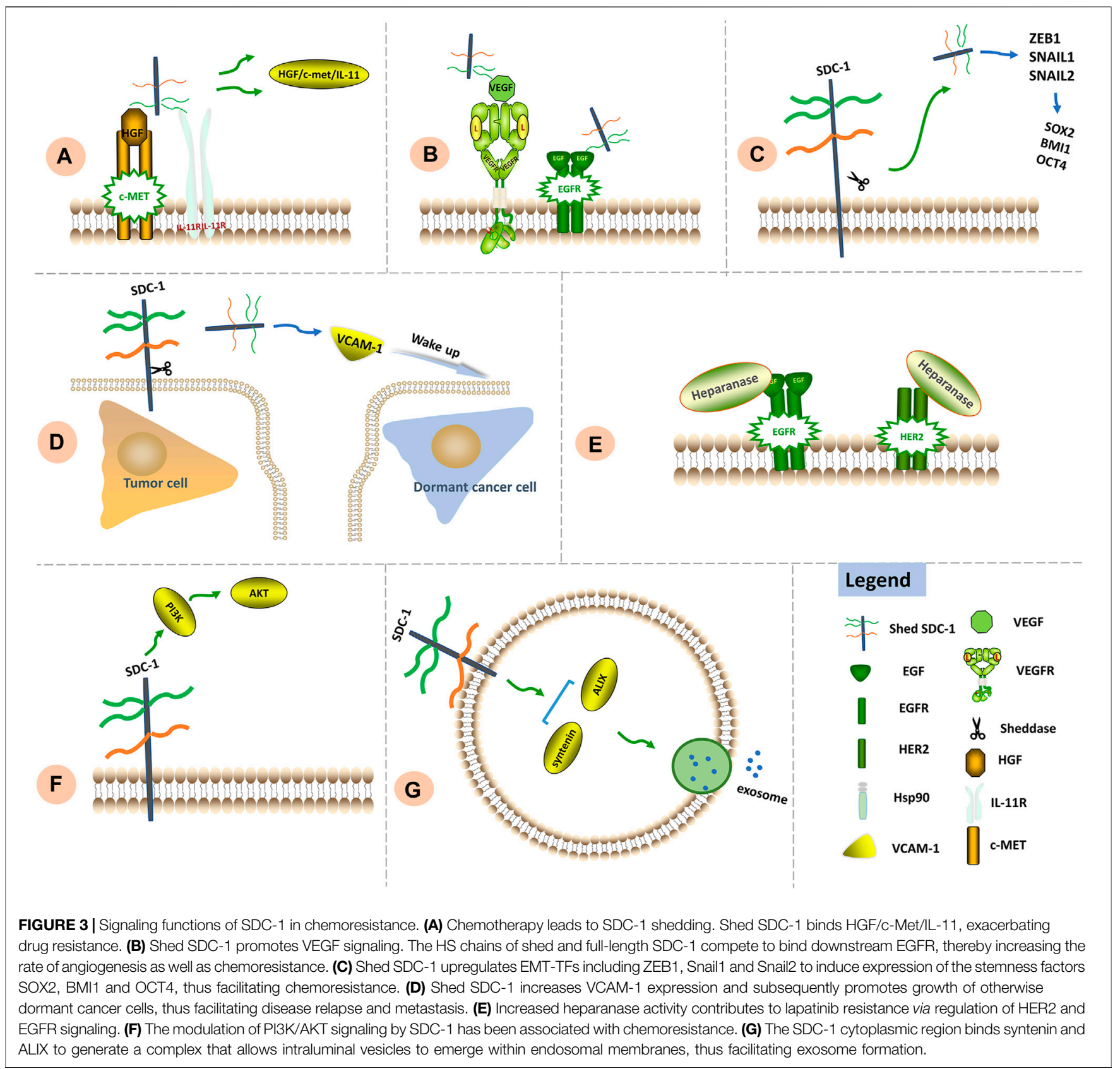

interaction is likely necessary for FAK activation and the subsequent upregulation of MMP-2 and MMP-9, important steps in tumor metastasis. The combinative polypeptide CBD-HepII inhibits expression of $\alpha \mathrm{V} \beta 3$ and SDC-1, thus decreasing interactions between these two receptors in B16 melanoma cells and inhibiting pulmonary metastasis of tumor cells in the circulation (Gong et al., 2008). Increased cell migration, invasion and MMP production are positively correlated with the co-localization of $\beta 1$ integrin and SDC- 1 in breast cancer cells (Gong et al., 2008). As such, the prevention of SDC- 1 and $\beta 1$ integrin co-localization is considered to be a potentially effective therapeutic strategy. Synstatin, peptide mimetics of the docking motifs in the syndecans, disrupts interaction among integrins, IGFR1, VEGFR and SDC-1, thereby resulting in significantly decreased angiogenesis and tumorigenesis in vivo (Beauvais et al., 2009; Rapraeger, 2013; Rapraeger et al., 2013; Gao et al., 2021).

\section{Targeting of Shed SDC-1}

Batimastat (BB-94), a broad-spectrum MMP inhibitor that also inhibits SDC-1 shedding, reduces ascites and disrupts breast, ovarian and colorectal carcinogenesis (Macaulay et al., 1999). NCS 405020, another small-molecule inhibitor that prevents the homodimerization of MT1-MMP, blocks the activity of this complex in vivo and reduces SDC-1 shedding (Remacle et al., 2012). Benzo $(\alpha)$ pyrene was found to promote pulmonary 
carcinogenesis in BALB/C mice via increased shedding of SDC-1 from epithelial cells, whereas all-trans retinoic acid (A-TRA) was found to block this process (Ramya et al., 2012). Use of MMP inhibitors and A-TRA has been suggested in conjunction with chemotherapy to avoid the potentially severe side effects of cancer progression or recurrence caused by chemotherapy-induced SDC-1 shedding (Kawano et al., 2013; Ali et al., 2019). Tranexamic acid, another therapy identified as a serine protease inhibitor that prevents SDC-1 shedding, may potentially serve as an inhibitor of metastasis in certain predisposed patients (Diebel et al., 2018). Antithrombin III, a plasma protein with both potent anticoagulant and antiinflammatory properties, also prevents SDC-1 shedding and thus plays roles in protection of the endothelial barrier and inhibition of metastasis (Lopez et al., 2020).

\section{Heparan Sulfate-Based Therapy}

Heparanase cleaves the HS chains of SDC-1 at certain locations, and heparanase inhibition decreases SDC-1 shedding. Although heparin is a heparanase inhibitor, it is not clinically utilized in cancer therapy due to its anti-coagulant effect. Heparin-combination therapy is developed and widely used (Casu et al., 2007). Use of modified heparin, small molecule inhibitors and function-blocking monoclonal antibodies are other methods of heparanase inhibition (Ramani et al., 2013). For example, SST0001, a modified heparin, significantly reduces in vivo heparanase activity and controls levels of growth factors including HGF and VEGF, thereby preventing angiogenesis in human pediatric sarcoma models (Cassinelli et al., 2013). The molecule M402 with a $6 \mathrm{kDa}$ molecular weight differs from SST0001 as it lacks N-acetylation and likely has a broader spectrum of growth factor-binding (Zhou et al., 2011; Kaur et al., 2021). Such heparin mimics effectively disturb the tumor microenvironment and are even more effective when combined with medications that directly target tumor cells. Preclinical studies have revealed that SST0001 in combination with dexamethasone exerts a significant anti-tumor effect in multiple myeloma xenograft mouse models, markedly reducing the subcutaneous growth of different multiple myeloma cell lines (Ritchie et al., 2011). Importantly, as both SDC-1 and heparanase participate in exosome generation, heparanase inhibition reduces tumor growth as well as exosomederived tumor recurrence ( $\mathrm{Wu}$ et al., 2021). The inhibition of proteolysis in the ED of SDC-1 is another method that targets SDC-1 shedding. As noted above, commonly used chemotherapy and radiation regimens promote heparanase upregulation and increase SDC-1 shedding in malignancies such as myeloma (Bandari et al., 2018), pancreatic cancer (Ramani and Sanderson, 2014) and medulloblastoma (Asuthkar et al., 2014). The monoclonal antibodies 9E8 and H1023 neutralize heparanase enzymatic activity and prevent spontaneous hepatic metastasis of ESb lymphoma cells from the primary tumor (Weissmann et al., 2016). Ovarian cancer cell proliferation and migration is effectively suppressed by PG545, a completely sulfated synthetic tetrasaccharide with anti-heparanase activity, when treatment is combined with paclitaxel and cisplatin (Winterhoff et al., 2015). Suramin is another small molecule inhibitor that reduces heparanase activity and inhibits FGF-2 and caspase-3 expression (Tayel et al., 2014). Heparanase activity is similarly inhibited by PI-88, an HS-like sulfated oligosaccharide.
Preliminary clinical trials of hepatocellular carcinoma patients treated with PI-88 have revealed significantly decreased levels of metastasis and disease recurrence (Liao et al., 2016). Lately, a newly synthesized triazolo-thiadiazoles (4-MMI) has been shown to successfully inhibit enzymatic heparanase activity and heparanase-mediated VEGF gene expression, restraining the ability of carcinoma cells to extravasate through the subendothelial basement membrane. It's shown that 4-MMI yield a nearly fourfold inhibition of 4T1 breast carcinoma metastasis, comparable to the effect exerted by roneparstat (Barash et al., 2021).

\section{Other Promising Therapies}

Methods that directly interfere with sheddase access to cleavages sites or stabilize the SDC-1 core protein into a confirmation less prone to proteolysis may also be good strategies to control SDC-1 shedding and subsequent tumor progression. The shedding of SDC- 1 is modulated by the intracellular binding of the small GTPase Rab5 to the SDC-1 CD; Rab5 dissociation from the SDC1 CD results in SDC-1 shedding and prevention of syndecanRab5 complex dissociation is thus considered to be another promising approach (Hayashida et al., 2008).

Creation of anti-tumor HS fragments can be accomplished by degrading $\mathrm{HS}$ in vitro with a bacterial enzyme and then administering the resultant fragments to tumor-bearing mice. This method has successfully stopped tumorigenesis in animal models of melanoma and myeloma (Liu et al., 2002; Yang et al., 2007). Although targeting proteoglycan remains more challenging than targeting heparanase, therapeutic potential has nevertheless been demonstrated with the former strategy. Hydrophobic aglycones can be used to disrupt the normal assembly of glycosaminoglycan chains on proteoglycan core proteins, stimulating the production of antiproliferative glycosaminoglycans and inhibiting proteoglycan synthesis. As a result, tumor progression and angiogenesis can potentially be prevented (Tsuzuki et al., 2010). Drugs targeting SDC-1 or SDC1-related proteins are shown in Table 1.

\section{ROLE OF MICRORNAS IN SDC-1 ACTIVITY AND TUMOR DEVELOPMENT}

MicroRNA (miRNA), a class of short non-coding RNA, exerts its effects via the modulation of target gene expression at the posttranscriptional stage. Indeed, miRNA is capable of controlling heparanase/SDC-1/shed SDC-1 gene transcription in the setting of malignancy. The SDC- 1 mRNA $3^{\prime}$-UTR is a direct target of miR494, miR-515-5p and miR-302a. Notably, reduction in miR-494 levels results in enhanced SDC-1 shedding and angiogenesis in medulloblastoma cells, while miR-302a and miR-515-5p inhibit ovarian and bladder cancer cell growth correspondingly via the targeting of SDC-1 (Asuthkar et al., 2014; Guo et al., 2015; Cao et al., 2021). As such, miR-155-based artificial miRNA and lentiviral miR30-based RNA can both target heparanase to suppress melanoma cell adhesion, migration and invasiveness in vitro (Liu et al., 2012; Liu et al., 2013). Syndecan binding protein (SDCBP), an adapter protein possessing PDZ domains, is known to interact with SDC-1 and be a target of both miR-135a-5p/miR-124-3p as well as miR- 
TABLE 1 | Drugs targeting SDC-1 or SDC-1-related proteins.

\begin{tabular}{|c|c|c|c|c|c|c|}
\hline Target & Drug name & Chemical type & $\begin{array}{l}\text { Mechanism of } \\
\text { action }\end{array}$ & Effect & Cancer & References \\
\hline \multirow[t]{6}{*}{ SDC-1 } & Zoledronic acid & $\begin{array}{l}\text { Resembles endogenous } \\
\text { pyrophosphate }\end{array}$ & $\begin{array}{l}\text { Disruption of SDC-1/ } \\
\text { integrins cross-talk }\end{array}$ & $\begin{array}{l}\text { Inhibition of SDC-1 and } \alpha v \beta 3 \\
\text { integrin protein expression }\end{array}$ & $\begin{array}{l}\text { Myeloma cells; } \\
\text { breast cancer }\end{array}$ & Dedes et al. (2012) \\
\hline & Nimesulide & $\begin{array}{l}\text { Non-steroidal anti- } \\
\text { inflammatory drug }\end{array}$ & $\begin{array}{l}\text { Inhibition of SDC-1 } \\
\text { expression }\end{array}$ & Inhibition of cell migration & $\begin{array}{l}\text { Primary effusion } \\
\text { lymphoma }\end{array}$ & $\begin{array}{l}\text { George Paul et al. } \\
\text { (2011) }\end{array}$ \\
\hline & $\begin{array}{l}\text { Indatuximab } \\
\text { ravtansine } \\
\text { (BT062-DM4) }\end{array}$ & $\begin{array}{l}\text { Antibody-drug conjugate } \\
\text { to cytotoxic agent (DM4) }\end{array}$ & $\begin{array}{l}\text { Cytotoxic action in the } \\
\text { target cell }\end{array}$ & $\begin{array}{l}\text { Specific SDC- } 1^{+} \text {cell death; } \\
\text { inhibition of tumor cell growth } \\
\text { and proliferation }\end{array}$ & Multiple myeloma & $\begin{array}{l}\text { Schönfeld et al. (2017), } \\
\text { Jagannath et al. (2019) }\end{array}$ \\
\hline & $\mathrm{OC}-46 \mathrm{~F} 2$ & Recombinant antibody & $\begin{array}{l}\text { Inhibition of SDC-1/ } \\
\text { VEGFR2 interaction }\end{array}$ & $\begin{array}{l}\text { Inhibition of vascular maturation } \\
\text { and tumor growth }\end{array}$ & $\begin{array}{l}\text { Malignant } \\
\text { melanoma and } \\
\text { ovarian cancer }\end{array}$ & Orecchia et al. (2013) \\
\hline & $\begin{array}{l}\text { (CDB-Hepll) } \\
\text { polypeptide }\end{array}$ & Polypeptide & $\begin{array}{l}\text { Reduction in } \alpha \vee \beta 3 \\
\text { integrin and SDC-1, } \\
\text { interaction }\end{array}$ & $\begin{array}{l}\text { Inhibition of pulmonary } \\
\text { metastasis }\end{array}$ & Melanoma & Gong et al. (2008) \\
\hline & Synstatin & Peptide & $\begin{array}{l}\text { Competition with SDC- } \\
1 \text { to bind receptors }\end{array}$ & $\begin{array}{l}\text { Blockage of the SDC- } 1 \text { core } \\
\text { protein active site; suppression } \\
\text { of the EGFR/a6 } \beta 4 \text { integrin } \\
\text { complex; inhibition of } \\
\text { angiogenesis }\end{array}$ & $\begin{array}{l}\text { Multiple myeloma; } \\
\text { mammary tumors }\end{array}$ & $\begin{array}{l}\text { Beauvais et al. (2009), } \\
\text { Rapraeger (2013), } \\
\text { Rapraeger et al. (2013), } \\
\text { Gao et al. (2021) }\end{array}$ \\
\hline \multirow[t]{5}{*}{$\begin{array}{l}\text { Shed } \\
\text { SDC-1 }\end{array}$} & $\begin{array}{l}\text { Batimastat } \\
\text { (BB-94) }\end{array}$ & Small molecule & MMP inhibition & $\begin{array}{l}\text { Inhibition of SDC-1 shedding; } \\
\text { prevention of tumor progression }\end{array}$ & $\begin{array}{l}\text { Breast, ovarian, } \\
\text { and colorectal } \\
\text { cancer }\end{array}$ & Macaulay et al. (1999) \\
\hline & NCS 405020 & Small molecule & $\begin{array}{l}\text { Inhibit the } \\
\text { homodimerization of } \\
\text { MT1-MMP }\end{array}$ & $\begin{array}{l}\text { Reduction in SDC-1 shedding; } \\
\text { suppression of tumor growth and } \\
\text { invasion }\end{array}$ & Breast cancer & Remacle et al. (2012) \\
\hline & $\begin{array}{l}\text { All-trans retinoic } \\
\text { acid (A-TRA) }\end{array}$ & Micronutrient & - & $\begin{array}{l}\text { Reduction in SDC-1 shedding; } \\
\text { inhibition of cancer invasion/ } \\
\text { metastasis }\end{array}$ & Lung & Ramya et al. (2012) \\
\hline & Tranexamic acid & Synthetic lysine analogue & $\begin{array}{l}\text { Inhibition of serine } \\
\text { protease }\end{array}$ & $\begin{array}{l}\text { Reduction in SDC-1 shedding; } \\
\text { prevention of cancer metastasis }\end{array}$ & - & Diebel et al. (2018) \\
\hline & Antithrombin III & Protein & - & $\begin{array}{l}\text { Prevention of SDC- } 1 \text { shedding; } \\
\text { inhibition of metastasis }\end{array}$ & - & Lopez et al. (2020) \\
\hline \multirow[t]{8}{*}{$\begin{array}{l}\text { Heparan } \\
\text { Sulfate }\end{array}$} & Heparin & Anticoagulant drug & $\begin{array}{l}\text { Inhibition of heparanase } \\
\text { activity }\end{array}$ & $\begin{array}{l}\text { Hampering VEGF and FGF-2 } \\
\text { activity, anti-angiogenesis }\end{array}$ & Myeloma & Casu et al. (2007) \\
\hline & SST0001 & Modified heparin & Inhibition of heparanase & $\begin{array}{l}\text { Inhibition of HGF, VEGF, and } \\
\text { anti-angiogenesis }\end{array}$ & $\begin{array}{l}\text { Human pediatric } \\
\text { sarcoma models }\end{array}$ & Cassinelli et al. (2013) \\
\hline & M402 & Modified heparin & Inhibition of heparanase & $\begin{array}{l}\text { Anti-angiogenesis; inhibition of } \\
\text { metastasis }\end{array}$ & Melanoma & $\begin{array}{l}\text { Zhou et al. (2011), Kaur } \\
\text { et al. (2021) }\end{array}$ \\
\hline & 9E8, H1023 & $\begin{array}{l}\text { Heparanase-neutralizing } \\
\text { monoclonal antibodies }\end{array}$ & $\begin{array}{l}\text { Neutralization of } \\
\text { heparanase enzymatic } \\
\text { activity }\end{array}$ & Inhibition of metastasis & Lymphoma & Weissmann et al. (2016) \\
\hline & PG545 & $\begin{array}{l}\text { Sulfated synthetic } \\
\text { tetrasaccharide }\end{array}$ & Inhibition of heparanase & $\begin{array}{l}\text { Suppression of proliferation and } \\
\text { migration }\end{array}$ & Ovarian cancer & Winterhoff et al. (2015) \\
\hline & Suramin & $\begin{array}{l}\text { Polysulfonated } \\
\text { naphthylurea-based } \\
\text { small molecule }\end{array}$ & $\begin{array}{l}\text { Suppression of the } \\
\text { activity of heparinase } \\
\text { activity }\end{array}$ & $\begin{array}{l}\text { Inhibition of caspase-3/8/9 } \\
\text { activity; inhibition of FGF-2; } \\
\text { suppression of both intrinsic and } \\
\text { extrinsic apoptotic pathways }\end{array}$ & $\begin{array}{l}\text { Hepatocellular } \\
\text { carcinoma }\end{array}$ & Tayel et al. (2014) \\
\hline & $\mathrm{Pl}-88$ & Sulfated oligosaccharide & $\begin{array}{l}\text { Inhibition of heparanase } \\
\text { activity }\end{array}$ & $\begin{array}{l}\text { Prevention of cancer recurrence } \\
\text { and metastasis of cancer }\end{array}$ & $\begin{array}{l}\text { Hepatocellular } \\
\text { carcinoma }\end{array}$ & Liao et al. (2016) \\
\hline & 4-MMl & $\begin{array}{l}\text { Triazolo-thiadiazole } \\
\text { compounds }\end{array}$ & $\begin{array}{l}\text { Inhibition of heparanase } \\
\text { activity }\end{array}$ & $\begin{array}{l}\text { Prevention of carcinoma cell } \\
\text { invasion and metastasis; } \\
\text { downregulation of VEGF } \\
\text { expression }\end{array}$ & $\begin{array}{l}\text { Glioma; breast } \\
\text { cancer; myeloma }\end{array}$ & Barash et al. (2021) \\
\hline
\end{tabular}

361-5p. In vivo studies have revealed that SDCBP silencing or miR135a-5p/miR-124-3p and miR-361-5p overexpression resulted in a significant reduction in tumor growth among glioblastoma and gastric carcinoma cell-bearing animals (Lin et al., 2018; Qian et al., 2020). Other research has revealed a distinctly negative correlation between miR-135b-5p and SDCBP expression. Suppression of miR-135b-5p was found to be associated with facilitation of the EMT and migration of breast cancer cells.
Thus, miR-135b-5p acts in the early prevention of breast cancer metastasis by targeting SDCBP (Pu et al., 2019). In addition, microRNA such as miR-1273a is also involved in SDC-1associated chemoresistance. Expression of SDCBP is downregulated by miR-1273a. Overexpression of miR-1273a boosts cisplatin cytotoxicity while lower plasma exosome miR1273a levels and higher plasma SDCBP levels are associated with poorer therapeutic results among patients who underwent platinum- 
TABLE 2 | The targeting of SDC-1 and SDC-1-related proteins by microRNA.

\begin{tabular}{|c|c|c|c|c|}
\hline $\begin{array}{l}\text { Target } \\
\text { (gene) }\end{array}$ & Potential microRNA & Mechanism of action & Cancer & References \\
\hline \multirow[t]{3}{*}{ SDC-1 } & miR-494 & $\begin{array}{l}\text { Inhibition of SDC-1 shedding; inhibition of MMP-9, VEGF, and HIF1a; } \\
\text { suppression of angiogenesis }\end{array}$ & Medulloblastoma & $\begin{array}{l}\text { Asuthkar et al. } \\
\text { (2014) }\end{array}$ \\
\hline & miR-302a & $\begin{array}{l}\text { Inhibition of the transition from G1 to S phases; inhibition of cell growth; } \\
\text { increase in apoptosis }\end{array}$ & Ovarian cancer & Guo et al. (2015) \\
\hline & miR-515-5p & $\begin{array}{l}\text { Inhibition of cell proliferation, migration, invasion, and colony formation; } \\
\text { increase in rate of cell apoptosis }\end{array}$ & Bladder cancer & Cao et al. (2021) \\
\hline \multirow[t]{2}{*}{ Heparanase } & $\begin{array}{l}\text { miR-155-based artificial } \\
\text { miRNA }\end{array}$ & Suppression of melanoma cell adhesion, migration and invasiveness & Melanoma & Liu et al. (2012) \\
\hline & $\begin{array}{l}\text { Lentiviral miR-30-based RNA } \\
\text { interference }\end{array}$ & Suppression of melanoma cell adhesion, migration and invasiveness & Melanoma & Liu et al. (2013) \\
\hline \multirow[t]{4}{*}{ SDCBP } & miR-135a-5p/miR-124-3p & Inhibition of tumor growth; decrease in tumor size; prolong survival time & Glioblastoma & Lin et al. (2018) \\
\hline & miR-361-5p & Inhibition of cell proliferation and tumor growth; increase in apoptosis & Gastric carcinoma & Qian et al. (2020) \\
\hline & $\operatorname{miR}-135 b-5 p$ & Inhibition of the epithelial-mesenchymal transition; decrease in migration & Breast cancer & Pu et al. (2019) \\
\hline & $\operatorname{miR}-1273 a$ & Enhancement of cisplatin cytotoxicity; prevention of chemoresistance & $\begin{array}{l}\text { Non-small cell lung } \\
\text { cancer }\end{array}$ & Zhao et al. (2020) \\
\hline
\end{tabular}

based therapy and suffer advanced non-small-cell lung cancer (Zhao et al., 2020). Specific alterations in miRNA expression have been speculated to affect SDC-1 signaling and promote cancer progression. Future studies should focus on exploring the relationship between expression levels of specific microRNA and tumor phenotypes induced by SDC-1, whether microRNA expression levels can be reliably used as a prognostic indicator of SDC-1-related cancers, and possibly offer novel approaches for the targeting of SDC-1 to intervene in cancer pathogenesis. The targeting of SDC-1 or SDC-1-related proteins by miRNA is detailed in Table 2.

\section{DISCUSSION}

Pathologic SDC-1 expression interferes with complex molecular signals and impact tumor grade, invasiveness and prognosis. Available data have supported cell-surface binding, shedding and nuclear localization of SDC-1 to contribute to cancer progression, although study of such phenomena has remained unsystematic. Levels of SDC-1 expression have, however, been recognized as a prognostic marker in solid and hematologic cancers. As molecular biology and detection technology continues to advance, studies are increasingly focusing on the effects of cellular SDC-1 localization on cancer prognosis and disease phenotype. Shed SDC-1 promotes binding between growth factors and their receptors, or in other cases acts as decoy receptors. The intranuclear presence of SDC- 1 activates gene transcription and influences various physiological activities. Awareness of the different effects exerted by varying cellular SDC-1 localization, and especially of the role shed SDC-1 plays in aggressive cancer phenotypes, is of vital importance in furthering understanding of mechanisms relevant to cell growth and proliferation, angiogenesis, metastasis and chemoresistance. Importantly, SDC- 1 is a potentially attractive molecular target that can guide individualized cancer diagnosis and treatment.

Although available data is interesting, drawbacks in knowledge remain. Based on prior studies, specific associations between SDC1 expression in different cells and cancer occurrence in different tissues cannot be made. Likewise, correlations between tumor characteristics, SDC-1 localization and prognostic significance in the setting of different cancers warrant further research. As precision medicine continues to emerge, cancer treatment regimens increasingly require both cancer- and patient-specific individualization.

Further study of the roles SDC-1 plays in cancer metastasis and drug resistance warrants: a) exploration of which pathological SDC-1 expression responds to cancer progression more rapidly by analysis of cancer tissue, tissue adjacent to the tumor and bodily fluids; b) conduction of cohort studies evaluating the association between specific cancers and SDC-1-related molecular or genetic expression; c) determination of dysregulation of which domain (i.e., $\mathrm{CD}, \mathrm{TMD}$ or $\mathrm{ED}$ ) is decisive for cancer phenotype formation among various malignancies; d) quantification of SDC-1 expression in different domains in the setting of various disease (i.e., TNM) stages; and e) further exploration whether the pathological expression of SDC-1 is associated with a specific predisposition towards cancer metastasis.

In conclusion, SDC-1 is a promising biomarker that can contribute to cancer diagnosis and prognosis. This protein is critical in the future individualization of targeted therapies for patients suffering poorly prognostic malignancies with high relapse rates.

\section{AUTHOR CONTRIBUTIONS}

SG, XW, and TL: wrote the original draft. RZ, YW, LZ, QZ, and YH: reviewed and editing. The final submitted version was supervised and approved by LW and YS. The essay was written by all of the writers, and the final version was approved by all of them.

\section{FUNDING}

This work was supported by the National Natural Science Foundation of China, No. 81674069, 82174503. 


\section{REFERENCES}

Alexopoulou, A. N., Multhaupt, H. A. B., and Couchman, J. R. (2007). Syndecans in Wound Healing, Inflammation and Vascular Biology. Int. J. Biochem. Cel Biol. 39 (3), 505-528. doi:10.1016/j.biocel.2006.10.014

Ali, M. M., Mahmoud, A. M., Le Master, E., Levitan, I., and Phillips, S. A. (2019). Role of Matrix Metalloproteinases and Histone Deacetylase in Oxidative StressInduced Degradation of the Endothelial Glycocalyx. Am. J. Physiology-Heart Circulatory Physiol. 316 (3), H647-H663. doi:10.1152/ajpheart.00090.2018

Altemeier, W. A., Schlesinger, S. Y., Buell, C. A., Brauer, R., Rapraeger, A. C., Parks, W. C., et al. (2012). Transmembrane and Extracellular Domains of Syndecan-1 Have Distinct Functions in Regulating Lung Epithelial Migration and Adhesion. J. Biol. Chem. 287 (42), 34927-34935. doi:10.1074/jbc.M112.376814

Altemeier, W. A., Schlesinger, S. Y., Buell, C. A., Parks, W. C., and Chen, P. (2012). Syndecan-1 Controls Cell Migration by Activating Rap1 to Regulate Focal Adhesion Disassembly. J. Cel Sci 125 (Pt 21), 5188-5195. doi:10.1242/ jcs. 109884

Amin, R., Tripathi, K., and Sanderson, R. D. (2020). Nuclear Heparanase Regulates Chromatin Remodeling, Gene Expression and PTEN Tumor Suppressor Function. Cells 9 (9), 2038. doi:10.3390/cells9092038

Asuthkar, S., Velpula, K. K., Nalla, A. K., Gogineni, V. R., Gondi, C. S., and Rao, J. S. (2014). Irradiation-induced Angiogenesis Is Associated with an MMP-9-miR494-Syndecan-1 Regulatory Loop in Medulloblastoma Cells. Oncogene 33 (15), 1922-1933. doi:10.1038/onc.2013.151

Bandari, S. K., Purushothaman, A., Ramani, V. C., Brinkley, G. J., Chandrashekar, D. S., Varambally, S., et al. (2018). Chemotherapy Induces Secretion of Exosomes Loaded with Heparanase that Degrades Extracellular Matrix and Impacts Tumor and Host Cell Behavior. Matrix Biol. 65, 104-118. doi:10.1016/ j.matbio.2017.09.001

Barash, U., Rangappa, S., Mohan, C. D., Vishwanath, D., Boyango, I., Basappa, B., et al. (2021). New Heparanase-Inhibiting Triazolo-Thiadiazoles Attenuate Primary Tumor Growth and Metastasis. Cancers 13 (12), 2959. doi:10.3390/ cancers13122959

Beauvais, D. M., Ell, B. J., McWhorter, A. R., and Rapraeger, A. C. (2009). Syndecan-1 Regulates $\alpha v \beta 3$ and $\alpha v \beta 5$ Integrin Activation during Angiogenesis and Is Blocked by Synstatin, a Novel Peptide Inhibitor. J. Exp. Med. 206 (3), 691-705. doi:10.1084/jem.20081278

Bernfield, M., Götte, M., Park, P. W., Reizes, O., Fitzgerald, M. L., Lincecum, J., et al. (1999). Functions of Cell Surface Heparan Sulfate Proteoglycans. Annu. Rev. Biochem. 68, 729-777. doi:10.1146/annurev.biochem.68.1.729

Bertrand, J., and Bollmann, M. (2019). Soluble Syndecans: Biomarkers for Diseases and Therapeutic Options. Br. J. Pharmacol. 176 (1), 67-81. doi:10.1111/ bph.14397

Birbo, B., Madu, E. E., Madu, C. O., Jain, A., and Lu, Y. (2021). Role of HSP90 in Cancer. Int. J. Mol. Sci. 22 (19), 10317. doi:10.3390/ijms221910317

Birchmeier, C., Birchmeier, W., Gherardi, E., and Vande Woude, G. F. (2003). Met, Metastasis, Motility and More. Nat. Rev. Mol. Cel Biol 4 (12), 915-925. doi:10.1038/nrm1261

Bode, W., and Maskos, K. (2003). Structural Basis of the Matrix Metalloproteinases and Their Physiological Inhibitors, the Tissue Inhibitors of Metalloproteinases. Biol. Chem. 384 (6), 863-872. doi:10.1515/BC.2003.097

Boettner, B., and Van Aelst, L. (2009). Control of Cell Adhesion Dynamics by Rap1 Signaling. Curr. Opin. Cel Biol. 21 (5), 684-693. doi:10.1016/j.ceb.2009.06.004

Bourdon, M. A., Krusius, T., Campbell, S., Schwartz, N. B., and Ruoslahti, E. (1987). Identification and Synthesis of a Recognition Signal for the Attachment of Glycosaminoglycans to Proteins. Proc. Natl. Acad. Sci. 84 (10), 3194-3198. doi:10.1073/pnas.84.10.3194

Cao, G., Zhang, C., Tian, X., Jing, G., Zhou, X., and Yan, T. (2021). circCEP128 Knockdown Suppresses Bladder Cancer Progression via Regulating microRNA515-5p/SDC1 Axis. Cancer Manag. Res. 13, 2885-2896. doi:10.2147/ CMAR.S288229

Cassinelli, G., Lanzi, C., Tortoreto, M., Cominetti, D., Petrangolini, G., Favini, E., et al. (2013). Antitumor Efficacy of the Heparanase Inhibitor SST0001 Alone and in Combination with Antiangiogenic Agents in the Treatment of Human Pediatric Sarcoma Models. Biochem. Pharmacol. 85 (10), 1424-1432. doi:10.1016/j.bcp.2013.02.023
Casu, B., Vlodavsky, I., and Sanderson, R. D. (2007). Non-anticoagulant Heparins and Inhibition of Cancer. Pathophysiol Haemos Thromb. 36 (3-4), 195-203. doi:10.1159/000175157

Chakravarti, R., Sapountzi, V., and Adams, J. C. (2005). Functional Role of Syndecan-1 Cytoplasmic V Region in Lamellipodial Spreading, Actin Bundling, and Cell Migration. Mol. Biol. Cel 16 (8), 3678-3691. doi:10.1091/ mbc.e04-10-0907

Chen, W.-X., Liu, X.-m., Lv, M.-m., Chen, L., Zhao, J.-h., Zhong, S.-l., et al. (2014) Exosomes from Drug-Resistant Breast Cancer Cells Transmit Chemoresistance by a Horizontal Transfer of microRNAs. PLoS One 9 (4), e95240. doi:10.1371/ journal.pone.0095240

Chen, X., Zhao, H., Chen, C., Li, J., He, J., Fu, X., et al. (2020). The HPA/SDC1 axis Promotes Invasion and Metastasis of Pancreatic Cancer Cells by Activating EMT via FGF2 Upregulation. Oncol. Lett. 19 (1), 211-220. doi:10.3892/ ol.2019.11121

Cheng, K., Zhou, Y., and Neelamegham, S. (2017). DrawGlycan-SNFG: a Robust Tool to Render Glycans and Glycopeptides with Fragmentation Information. Glycobiology 27 (3), 200-205. doi:10.1093/glycob/cww115

Christianson, H. C., and Belting, M. (2014). Heparan Sulfate Proteoglycan as a Cell-Surface Endocytosis Receptor. Matrix Biol. 35, 51-55. doi:10.1016/ j.matbio.2013.10.004

Correia, A. L., Mori, H., Chen, E. I., Schmitt, F. C., and Bissell, M. J. (2013). The Hemopexin Domain of MMP3 Is Responsible for Mammary Epithelial Invasion and Morphogenesis through Extracellular Interaction with HSP90ß. Genes Dev. 27 (7), 805-817. doi:10.1101/gad.211383.112

Couchman, J. R. (2010). Transmembrane Signaling Proteoglycans. Annu. Rev. Cel Dev. Biol. 26, 89-114. doi:10.1146/annurev-cellbio-100109-104126

Das, S., Dixon, J. E., and Cho, W. (2003). Membrane-binding and Activation Mechanism of PTEN. Proc. Natl. Acad. Sci. 100 (13), 7491-7496. doi:10.1073/ pnas.0932835100

de Oliveira Neves, F. M., Araújo, C. B., de Freitas, D. F., Arruda, B. F. T., de Macêdo Filho, L. J. M., Salles, V. B., et al. (2019). Fibroblast Growth Factor 23, Endothelium Biomarkers and Acute Kidney Injury in Critically-Ill Patients. J. Transl Med. 17 (1), 121. doi:10.1186/s12967-019-1875-6

De Rossi, G., and Whiteford, J. R. (2013). Novel Insight into the Biological Functions of Syndecan Ectodomain Core Proteins. Biofactors 39 (4), 374-382. doi:10.1002/biof.1104

Dedes, P. G., Gialeli, C., Tsonis, A. I., Kanakis, I., Theocharis, A. D., Kletsas, D., et al. (2012). Expression of Matrix Macromolecules and Functional Properties of Breast Cancer Cells Are Modulated by the Bisphosphonate Zoledronic Acid. Biochim. Biophys. Acta (Bba) - Gen. Subjects 1820 (12), 1926-1939. doi:10.1016/ j.bbagen.2012.07.013

Diebel, M. E., Martin, J. V., Liberati, D. M., and Diebel, L. N. (2018). The Temporal Response and Mechanism of Action of Tranexamic Acid in Endothelial Glycocalyx Degradation. J. Trauma Acute Care Surg. 84 (1), 75-80. doi:10.1097/TA.0000000000001726

Dudás, J., Ramadori, G., Knittel, T., Neubauer, K., Raddatz, D., Egedy, K., et al. (2000). Effect of Heparin and Liver Heparan Sulphate on Interaction of HepG2Derived Transcription Factors and Their Cis-Acting Elements: Altered Potential of Hepatocellular Carcinoma Heparan Sulphate. Biochem. J. 350 (Pt 1), 245-251. doi:10.1042/bj3500245

Duverger, E., Pellerin-Mendes, C., Mayer, R., Roche, A. C., and Monsigny, M. (1995). Nuclear Import of Glycoconjugates Is Distinct from the Classical NLS Pathway. J. Cel Sci 108 (Pt 4), 1325-1332. doi:10.1242/jcs.108.4.1325

El Masri, R., Crétinon, Y., Gout, E., and Vivès, R. R. (2020). HS and Inflammation: A Potential Playground for the Sulfs. Front. Immunol. 11, 570. doi:10.3389/ fimmu.2020.00570

Farfán, N., Orellana-Serradell, O., Herrera, D., Chrzanowsky, D., Cubillos, P., Marán, G., et al. (2020). SNAIL Expression Correlates with the Translocation of Syndecan-1 I-ntracellular D-omain into the N-ucleus in P-rostate C-ancer C-ell L-ines. Int. J. Mol. Med. 45 (4), 1073-1080. doi:10.3892/ijmm.2020.4488

Gao, J., Xu, Y., Liu, J., and Huang, X. (2021). Convergent Chemoenzymatic Synthesis and Biological Evaluation of a Heparan Sulfate Proteoglycan Syndecan-1 Mimetic. Chem. Commun. 57 (27), 3407-3410. doi:10.1039/ d1cc00796c

George Paul, A., Sharma-Walia, N., and Chandran, B. (2011). Targeting KSHV/ HHV-8 Latency with COX-2 Selective Inhibitor Nimesulide: a Potential 
Chemotherapeutic Modality for Primary Effusion Lymphoma. PLoS One 6 (9), e24379. doi:10.1371/journal.pone.0024379

Gomis-Rüth, F. X. (2009). Catalytic Domain Architecture of Metzincin Metalloproteases. J. Biol. Chem. 284 (23), 15353-15357. doi:10.1074/ jbc.R800069200

Gong, W., Liu, Y., Huang, B., Lei, Z., Wu, F.-H., Li, D., et al. (2008). Recombinant CBD-HepII Polypeptide of Fibronectin Inhibits av $\beta 3$ Signaling and Hematogenous Metastasis of Tumor. Biochem. Biophysical Res. Commun. 367 (1), 144-149. doi:10.1016/j.bbrc.2007.12.110

Götte, M., Kersting, C., Ruggiero, M., Tio, J., Tulusan, A. H., Kiesel, L., et al. (2006). Predictive Value of Syndecan-1 Expression for the Response to Neoadjuvant Chemotherapy of Primary Breast Cancer. Anticancer Res. 26 (1B), 621-627.

Guo, T., Yu, W., Lv, S., Zhang, C., and Tian, Y. (2015). MiR-302a Inhibits the Tumorigenicity of Ovarian Cancer Cells by Suppression of SDC1. Int. J. Clin. Exp. Pathol. 8 (5), 4869-4880.

Hadigal, S., Koganti, R., Yadavalli, T., Agelidis, A., Suryawanshi, R., and Shukla, D. (2020). Heparanase-Regulated Syndecan-1 Shedding Facilitates Herpes Simplex Virus 1 Egress. J. Virol. 94 (6), 94. doi:10.1128/JVI.01672-19

Hayashida, K., Stahl, P. D., and Park, P. W. (2008). Syndecan-1 Ectodomain Shedding Is Regulated by the Small GTPase Rab5. J. Biol. Chem. 283 (51), 35435-35444. doi:10.1074/jbc.M804172200

Hoffman, M. P., Nomizu, M., Roque, E., Lee, S., Jung, D. W., Yamada, Y., et al. (1998). Laminin-1 and Laminin-2 G-Domain Synthetic Peptides Bind Syndecan-1 and Are Involved in Acinar Formation of a Human Submandibular Gland Cell Line. J. Biol. Chem. 273 (44), 28633-28641. doi:10.1074/jbc.273.44.28633

Ingvarsen, S. Z., Gårdsvoll, H., van Putten, S., Nørregaard, K. S., Krigslund, O., Meilstrup, J. A., et al. (2020). Tumor Cell MT1-MMP Is Dispensable for Osteosarcoma Tumor Growth, Bone Degradation and Lung Metastasis. Sci. Rep. 10 (1), 19138. doi:10.1038/s41598-020-75995-6

Jagannath, S., Heffner, L. T., Jr., Ailawadhi, S., Munshi, N. C., Zimmerman, T. M., Rosenblatt, J., et al. (2019). Indatuximab Ravtansine (BT062) Monotherapy in Patients with Relapsed And/or Refractory Multiple Myeloma. Clin. Lymphoma Myeloma Leuk. 19 (6), 372-380. doi:10.1016/j.clml.2019.02.006

Javadi, J., Dobra, K., and Hjerpe, A. (2020). Multiplex Soluble Biomarker Analysis from Pleural Effusion. Biomolecules 10 (8), 1113. doi:10.3390/biom10081113

Jenkins, L. M., Horst, B., Lancaster, C. L., and Mythreye, K. (2018). Dually Modified Transmembrane Proteoglycans in Development and Disease. Cytokine Growth Factor. Rev. 39, 124-136. doi:10.1016/j.cytogfr.2017.12.003

Jung, O., Trapp-Stamborski, V., Purushothaman, A., Jin, H., Wang, H., Sanderson, R. D., et al. (2016). Heparanase-induced Shedding of syndecan-1/CD138 in Myeloma and Endothelial Cells Activates VEGFR2 and an Invasive Phenotype: Prevention by Novel Synstatins. Oncogenesis 5-e202. doi:10.1038/oncsis.2016.5

Kaur, R., Deb, P. K., Diwan, V., and Saini, B. (2021). Heparanase Inhibitors in Cancer Progression: Recent Advances. Curr. Pharm. Des. 27 (1), 43-68. doi:10.2174/1381612826666201113105250

Kawano, Y., Kikukawa, Y., Fujiwara, S., Wada, N., Okuno, Y., Mitsuya, H., et al. (2013). Hypoxia Reduces CD138 Expression and Induces an Immature and Stem Cell-like Transcriptional Program in Myeloma Cells. Int. J. Oncol. 43 (6), 1809-1816. doi:10.3892/ijo.2013.2134

Kovalszky, I., Dudás, J., Oláh-Nagy, J., Pogány, G., Töváry, J., Timár, J., et al. (1998). Inhibition of DNA Topoisomerase I Activity by Heparan Sulfate and Modulation by Basic Fibroblast Growth Factor. Mol. Cel Biochem 183 (1-2), 11-23. doi:10.1023/a:1006898920637

Kumar-Singh, A., Parniewska, M. M., Giotopoulou, N., Javadi, J., Sun, W., Szatmári, T., et al. (2021). Nuclear Syndecan-1 Regulates EpithelialMesenchymal Plasticity in Tumor Cells. Biology 10 (6), 521. doi:10.3390/ biology 10060521

Kumar-Singh, A., Shrinet, J., Parniewska, M. M., Fuxe, J., Dobra, K., and Hjerpe, A. (2020). Mapping the Interactome of the Nuclear Heparan Sulfate Proteoglycan Syndecan-1 in Mesothelioma Cells. Biomolecules 10 (7), 1034. doi:10.3390/ biom10071034

Liao, B.-Y., Wang, Z., Hu, J., Liu, W.-F., Shen, Z.-Z., Zhang, X., et al. (2016). PI-88 Inhibits Postoperative Recurrence of Hepatocellular Carcinoma via Disrupting the Surge of Heparanase after Liver Resection. Tumor Biol. 37 (3), 2987-2998. doi:10.1007/s13277-015-4085-8

Lin, J., Wen, X., Zhang, X., Sun, X., Yunzhi, L., Peng, R., et al. (2018). miR-135a-5p and miR-124-3p Inhibit Malignancy of Glioblastoma by Downregulation of
Syndecan Binding Protein. J. Biomed. Nanotechnol 14 (7), 1317-1329. doi:10.1166/jbn.2018.2579

Liu, D., Shriver, Z., Venkataraman, G., El Shabrawi, Y., and Sasisekharan, R. (2002). Tumor Cell Surface Heparan Sulfate as Cryptic Promoters or Inhibitors of Tumor Growth and Metastasis. Proc. Natl. Acad. Sci. 99 (2), 568-573. doi:10.1073/pnas.012578299

Liu, R., Chen, Y., Liu, G., Li, C., Song, Y., Cao, Z., et al. (2020). PI3K/AKT Pathway as a Key Link Modulates the Multidrug Resistance of Cancers. Cell Death Dis 11 (9), 797. doi:10.1038/s41419-020-02998-6

Liu, X.-y., Tang, Q.-s., Chen, H.-c., Jiang, X.-l., and Fang, H. (2013). Lentiviral miR30-Based RNA Interference against Heparanase Suppresses Melanoma Metastasis with Lower Liver and Lung Toxicity. Int. J. Biol. Sci. 9 (6), 564-577. doi:10.7150/ijbs.5425

Liu, X., Fang, H., Chen, H., Jiang, X., Fang, D., Wang, Y., et al. (2012). An Artificial miRNA against HPSE Suppresses Melanoma Invasion Properties, Correlating with a Down-Regulation of Chemokines and MAPK Phosphorylation. PLoS One 7 (6), e38659. doi:10.1371/journal.pone.0038659

Loh, C.-Y., Chai, J., Tang, T., Wong, W., Sethi, G., Shanmugam, M., et al. (2019). The E-Cadherin and N-Cadherin Switch in Epithelial-To-Mesenchymal Transition: Signaling, Therapeutic Implications, and Challenges. Cells 8 (10), 1118. doi:10.3390/cells 8101118

Lopez, E., Peng, Z., Kozar, R. A., Cao, Y., Ko, T. C., Wade, C. E., et al. (2020). Antithrombin III Contributes to the Protective Effects of Fresh Frozen Plasma Following Hemorrhagic Shock by Preventing Syndecan-1 Shedding and Endothelial Barrier Disruption. Shock 53 (2), 156-163. doi:10.1097/ SHK.0000000000001432

Lu, X., Mu, E., Wei, Y., Riethdorf, S., Yang, Q., Yuan, M., et al. (2011). VCAM-1 Promotes Osteolytic Expansion of Indolent Bone Micrometastasis of Breast Cancer by Engaging a $4 \beta 1$-Positive Osteoclast Progenitors. Cancer Cell 20 (6), 701-714. doi:10.1016/j.ccr.2011.11.002

Macaulay, V. M., O'Byrne, K. J., Saunders, M. P., Braybrooke, J. P., Long, L., Gleeson, F., et al. (1999). Phase I Study of Intrapleural Batimastat (BB-94), a Matrix Metalloproteinase Inhibitor, in the Treatment of Malignant Pleural Effusions. Clin. Cancer Res. 5 (3), 513-520.

Maday, S., Anderson, E., Chang, H. C., Shorter, J., Satoh, A., Sfakianos, J., et al. (2008). A PDZ-Binding Motif Controls Basolateral Targeting of Syndecan-1 along the Biosynthetic Pathway in Polarized Epithelial Cells. Traffic 9 (11), 1915-1924. doi:10.1111/j.1600-0854.2008.00805.X

Manon-Jensen, T., Itoh, Y., and Couchman, J. R. (2010). Proteoglycans in Health and Disease: the Multiple Roles of Syndecan Shedding. FEBS J. 277 (19), 3876-3889. doi:10.1111/j.1742-4658.2010.07798.x

Masola, V., Secchi, M., Gambaro, G., and Onisto, M. (2014). Heparanase as a Target in Cancer Therapy. Ccdt 14 (3), 286-293. doi:10.2174/ 1568009614666140224155124

Matsuo, I., and Kimura-Yoshida, C. (2013). Extracellular Modulation of Fibroblast Growth Factor Signaling through Heparan Sulfate Proteoglycans in Mammalian Development. Curr. Opin. Genet. Dev. 23 (4), 399-407. doi:10.1016/j.gde.2013.02.004

Millanes-Romero, A., Herranz, N., Perrera, V., Iturbide, A., Loubat-Casanovas, J., Gil, J., et al. (2013). Regulation of Heterochromatin Transcription by Snail1/ LOXL2 during Epithelial-To-Mesenchymal Transition. Mol. Cel 52 (5), 746-757. doi:10.1016/j.molcel.2013.10.015

Mulloy, B., Lever, R., and Page, C. P. (2017). Mast Cell Glycosaminoglycans. Glycoconj J. 34 (3), 351-361. doi:10.1007/s10719-016-9749-0

Mythreye, K., and Blobe, G. C. (2009). Proteoglycan Signaling Co-receptors: Roles in Cell Adhesion, Migration and Invasion. Cell Signal. 21 (11), 1548-1558. doi:10.1016/j.cellsig.2009.05.001

Nadanaka, S., Bai, Y., and Kitagawa, H. (2021). Cleavage of Syndecan-1 Promotes the Proliferation of the Basal-like Breast Cancer Cell Line BT-549 via Akt SUMOylation. Front. Cel Dev. Biol. 9, 659428. doi:10.3389/fcell.2021.659428

Nakamura, T., Sakai, K., Nakamura, T., and Matsumoto, K. (2011). Hepatocyte Growth Factor Twenty Years on: Much More Than a Growth Factor. J. Gastroenterol. Hepatol. 26 (Suppl. 1), 188-202. doi:10.1111/j.14401746.2010.06549.x

Ogawa, H., Shionyu, M., Sugiura, N., Hatano, S., Nagai, N., Kubota, Y., et al. (2010). Chondroitin Sulfate Synthase-2/Chondroitin Polymerizing Factor Has Two Variants with Distinct Function*. J. Biol. Chem. 285 (44), 34155-34167. doi:10.1074/jbc.M110.109553 
Ogawa, T., Tsubota, Y., Hashimoto, J., Kariya, Y., and Miyazaki, K. (2007). The Short Arm of Laminin $\gamma 2$ Chain of Laminin-5 (Laminin-332) Binds Syndecan-1 and Regulates Cellular Adhesion and Migration by Suppressing Phosphorylation of Integrin $\beta 4$ Chain. MBoC 18 (5), 1621-1633. doi:10.1091/mbc.e06-09-0806

Orecchia, P., Conte, R., Balza, E., Petretto, A., Mauri, P., Mingari, M. C., et al. (2013). A Novel Human Anti-syndecan-1 Antibody Inhibits Vascular Maturation and Tumour Growth in Melanoma. Eur. J. Cancer 49 (8), 2022-2033. doi:10.1016/j.ejca.2012.12.019

Pantel, K., and Brakenhoff, R. H. (2004). Dissecting the Metastatic cascade. Nat. Rev. Cancer 4 (6), 448-456. doi:10.1038/nrc1370

Park, P. W. (2016). Glycosaminoglycans and Infection. Front. Biosci. 21, 1260-1277. doi:10.2741/4455

Piperigkou, Z., Mohr, B., Karamanos, N., and Götte, M. (2016). Shed Proteoglycans in Tumor Stroma. Cell Tissue Res 365 (3), 643-655. doi:10.1007/s00441-016$2452-4$

Pradella, D., Naro, C., Sette, C., and Ghigna, C. (2017). EMT and Stemness: Flexible Processes Tuned by Alternative Splicing in Development and Cancer Progression. Mol. Cancer 16 (1), 8. doi:10.1186/s12943-016-0579-2

$\mathrm{Pu}$, T., Shen, M., Li, S., Yang, L., Gao, H., Xiao, L., et al. (2019). Repression of miR135b-5p Promotes Metastasis of Early-Stage Breast Cancer by Regulating Downstream Target SDCBP. Lab. Invest. 99 (9), 1296-1308. doi:10.1038/ s41374-019-0258-1

Purushothaman, A., Hurst, D. R., Pisano, C., Mizumoto, S., Sugahara, K., and Sanderson, R. D. (2011). Heparanase-mediated Loss of Nuclear Syndecan-1 Enhances Histone Acetyltransferase (HAT) Activity to Promote Expression of Genes that Drive an Aggressive Tumor Phenotype. J. Biol. Chem. 286 (35), 30377-30383. doi:10.1074/jbc.M111.254789

Purushothaman, A., and Sanderson, R. D. (2020). Heparanase: A Dynamic Promoter of Myeloma Progression. Adv. Exp. Med. Biol. 1221, 331-349. doi:10.1007/978-3-030-34521-1_12

Purushothaman, A., Uyama, T., Kobayashi, F., Yamada, S., Sugahara, K., Rapraeger, A. C., et al. (2010). Heparanase-enhanced Shedding of Syndecan1 by Myeloma Cells Promotes Endothelial Invasion and Angiogenesis. Blood 115 (12), 2449-2457. doi:10.1182/blood-2009-07-234757

Qian, B., Zhang, D., Tao, R., Yu, G., Jia, B., Ye, K., et al. (2020). MiR-361-5p Exerts Tumor-Suppressing Functions in Gastric Carcinoma by Targeting SyndecanBinding Protein. Anticancer Drugs 31 (2), 131-140. doi:10.1097/ CAD. 0000000000000846

Ramani, V. C., Purushothaman, A., Stewart, M. D., Thompson, C. A., Vlodavsky, I., $\mathrm{Au}, \mathrm{J}$. L.-S., et al. (2013). The Heparanase/syndecan-1 axis in Cancer: Mechanisms and Therapies. FEBS J. 280 (10), 2294-2306. doi:10.1111/ febs. 12168

Ramani, V. C., and Sanderson, R. D. (2014). Chemotherapy Stimulates Syndecan-1 Shedding: a Potentially Negative Effect of Treatment that May Promote Tumor Relapse. Matrix Biol. 35, 215-222. doi:10.1016/ j.matbio.2013.10.005

Ramani, V. C., Vlodavsky, I., Ng, M., Zhang, Y., Barbieri, P., Noseda, A., et al. (2016). Chemotherapy Induces Expression and Release of Heparanase Leading to Changes Associated with an Aggressive Tumor Phenotype. Matrix Biol. 55, 22-34. doi:10.1016/j.matbio.2016.03.006

Ramani, V. C., Yang, Y., Ren, Y., Nan, L., and Sanderson, R. D. (2011). Heparanase Plays a Dual Role in Driving Hepatocyte Growth Factor (HGF) Signaling by Enhancing HGF Expression and Activity. J. Biol. Chem. 286 (8), 6490-6499. doi:10.1074/jbc.M110.183277

Ramya, D., Siddikuzzaman, and Grace, V. M. B. (2012). Effect of All-Transretinoic Acid (ATRA) on Syndecan-1 Expression and its Chemoprotective Effect in Benzo(a)pyrene-Induced Lung Cancer Mice Model. Immunopharmacology and Immunotoxicology 34 (6), 1020-1027. doi:10.3109/08923973.2012.693086

Rangarajan, S., Richter, J. R., Richter, R. P., Bandari, S. K., Tripathi, K., Vlodavsky, I., et al. (2020). Heparanase-enhanced Shedding of Syndecan-1 and its Role in Driving Disease Pathogenesis and Progression. J. Histochem. Cytochem. 68 (12), 823-840. doi:10.1369/0022155420937087

Rapraeger, A. C., Ell, B. J., Roy, M., Li, X., Morrison, O. R., Thomas, G. M., et al. (2013). Vascular Endothelial-Cadherin Stimulates Syndecan-1-Coupled Insulin-like Growth Factor-1 Receptor and Cross-Talk between $\alpha \mathrm{V} \beta 3$ Integrin and Vascular Endothelial Growth Factor Receptor 2 at the Onset of
Endothelial Cell Dissemination during Angiogenesis. FEBS J. 280 (10), 2194-2206. doi:10.1111/febs.12134

Rapraeger, A. C. (2013). Synstatin: a Selective Inhibitor of the Syndecan-1-Coupled IGF1R-Av $\beta 3$ Integrin Complex in Tumorigenesis and Angiogenesis. FEBS J. 280 (10), 2207-2215. doi:10.1111/febs.12160

Remacle, A. G., Golubkov, V. S., Shiryaev, S. A., Dahl, R., Stebbins, J. L., Chernov, A. V., et al. (2012). Novel MT1-MMP Small-Molecule Inhibitors Based on Insights into Hemopexin Domain Function in Tumor Growth. Cancer Res. 72 (9), 2339-2349. doi:10.1158/0008-5472.CAN-11-4149

Rhodes, J. M., and Simons, M. (2007). The Extracellular Matrix and Blood Vessel Formation: Not Just a Scaffold. J. Cell. Mol. Med. 11 (2), 176-205. doi:10.1111/ j.1582-4934.2007.00031.x

Ritchie, J. P., Ramani, V. C., Ren, Y., Naggi, A., Torri, G., Casu, B., et al. (2011). SST0001, a Chemically Modified Heparin, Inhibits Myeloma Growth and Angiogenesis via Disruption of the Heparanase/syndecan-1 axis. Clin. Cancer Res. 17 (6), 1382-1393. doi:10.1158/1078-0432.CCR-10-2476

Roucourt, B., Meeussen, S., Bao, J., Zimmermann, P., and David, G. (2015). Heparanase Activates the Syndecan-Syntenin-ALIX Exosome Pathway. Cell Res 25 (4), 412-428. doi:10.1038/cr.2015.29

Salmivirta, M., Mali, M., Heino, J., Hermonen, J., and Jalkanen, M. (1994). A Novel Laminin-Binding Form of Syndecan-1 (Cell Surface Proteoglycan) Produced by Syndecan-1 cDNA-Transfected NIH-3T3 Cells. Exp. Cel Res. 215 (1), 180-188. doi:10.1006/excr.1994.1330

Saunders, S., Jalkanen, M., O'Farrell, S., and Bernfield, M. (1989). Molecular Cloning of Syndecan, an Integral Membrane Proteoglycan. J. Cel Biol 108 (4), 1547-1556. doi:10.1083/jcb.108.4.1547

Schönfeld, K., Zuber, C., Pinkas, J., Häder, T., Bernöster, K., and Uherek, C. (2017). Indatuximab Ravtansine (BT062) Combination Treatment in Multiple Myeloma: Pre-clinical Studies. J. Hematol. Oncol. 10 (1), 13. doi:10.1186/ s13045-016-0380-0

Shteingauz, A., Boyango, I., Naroditsky, I., Hammond, E., Gruber, M., Doweck, I., et al. (2015). Heparanase Enhances Tumor Growth and Chemoresistance by Promoting Autophagy. Cancer Res. 75 (18), 3946-3957. doi:10.1158/00085472.CAN-15-0037

Sidera, K., Gaitanou, M., Stellas, D., Matsas, R., and Patsavoudi, E. (2008). A Critical Role for HSP90 in Cancer Cell Invasion Involves Interaction with the Extracellular Domain of HER-2. J. Biol. Chem. 283 (4), 2031-2041. doi:10.1074/ jbc.M701803200

Snigireva, A. V., Vrublevskaya, V. V., Skarga, Y. Y., and Morenkov, O. S. (2019). Cell Surface Heparan Sulfate Proteoglycans Are Involved in the Extracellular Hsp90-Stimulated Migration and Invasion of Cancer Cells. Cell Stress and Chaperones 24 (2), 309-322. doi:10.1007/s12192-018-0955-5

Stewart, M. D., Ramani, V. C., and Sanderson, R. D. (2015). Shed Syndecan-1 Translocates to the Nucleus of Cells Delivering Growth Factors and Inhibiting Histone Acetylation. J. Biol. Chem. 290 (2), 941-949. doi:10.1074/ jbc.M114.608455

Stewart, M. D., and Sanderson, R. D. (2014). Heparan Sulfate in the Nucleus and its Control of Cellular Functions. Matrix Biol. 35, 56-59. doi:10.1016/ j.matbio.2013.10.009

Szatmári, T., Mundt, F., Kumar-Singh, A., Möbus, L., Ötvös, R., Hjerpe, A., et al. (2017). Molecular Targets and Signaling Pathways Regulated by Nuclear Translocation of Syndecan-1. BMC Cel Biol 18 (1), 34. doi:10.1186/s12860017-0150-z

Tayel, A., Abd El Galil, K. H., Ebrahim, M. A., Ibrahim, A. S., El-Gayar, A. M., and Al-Gayyar, M. M. H. (2014). Suramin Inhibits Hepatic Tissue Damage in Hepatocellular Carcinoma through Deactivation of Heparanase Enzyme. Eur. J. Pharmacol. 728, 151-160. doi:10.1016/j.ejphar.2014.02.001

Tkachenko, E., Rhodes, J. M., and Simons, M. (2005). Syndecans. Circ. Res. 96 (5), 488-500. doi:10.1161/01.RES.0000159708.71142.c8

Tsuzuki, Y., Nguyen, T. K. N., Garud, D. R., Kuberan, B., and Koketsu, M. (2010). 4-deoxy-4-fluoro-xyloside Derivatives as Inhibitors of Glycosaminoglycan Biosynthesis. Bioorg. Med. Chem. Lett. 20 (24), 7269-7273. doi:10.1016/ j.bmcl.2010.10.085

Wang, S., Zhang, X., Wang, G., Cao, B., Yang, H., Jin, L., et al. (2019). Syndecan-1 Suppresses Cell Growth and Migration via Blocking JAK1/STAT3 and Ras/Raf/ MEK/ERK Pathways in Human Colorectal Carcinoma Cells. BMC Cancer 19 (1), 1160. doi:10.1186/s12885-019-6381-y 
Wang, X., Zuo, D., Chen, Y., Li, W., Liu, R., He, Y., et al. (2014). Shed Syndecan1 Is Involved in Chemotherapy Resistance via the EGFR Pathway in Colorectal Cancer. Br. J. Cancer 111 (10), 1965-1976. doi:10.1038/ bjc. 2014.493

Weissmann, M., Arvatz, G., Horowitz, N., Feld, S., Naroditsky, I., Zhang, Y., et al. (2016). Heparanase-neutralizing Antibodies Attenuate Lymphoma Tumor Growth and Metastasis. Proc. Natl. Acad. Sci. USA 113 (3), 704-709. doi:10.1073/pnas.1519453113

Winterhoff, B., Freyer, L., Hammond, E., Giri, S., Mondal, S., Roy, D., et al. (2015). PG545 Enhances Anti-cancer Activity of Chemotherapy in Ovarian Models and Increases Surrogate Biomarkers Such as VEGF in Preclinical and Clinical Plasma Samples. Eur. J. Cancer 51 (7), 879-892. doi:10.1016/ j.ejca.2015.02.007

Wu, X., Kang, M., Wang, D., Zhu, M., Hu, Y., Zhang, Y., et al. (2021). Heparan Sulfate Analogues Regulate Tumor-Derived Exosome Formation that Attenuates Exosome Functions in Tumor Processes. Int. J. Biol. Macromolecules 187, 481-491. doi:10.1016/j.ijbiomac.2021.07.110

Yang, Y., MacLeod, V., Dai, Y., Khotskaya-Sample, Y., Shriver, Z., Venkataraman, G., et al. (2007). The Syndecan-1 Heparan Sulfate Proteoglycan Is a Viable Target for Myeloma Therapy. Blood 110 (6), 2041-2048. doi:10.1182/blood2007-04-082495

Yu, L., Xu, H., Zhang, S., Chen, J., and Yu, Z. (2020). SDC1 Promotes Cisplatin Resistance in Hepatic Carcinoma Cells via PI3K-AKT Pathway. Hum. Cel 33 (3), 721-729. doi:10.1007/s13577-020-00362-6

Zhang, L., David, G., and Esko, J. D. (1995). Repetitive Ser-Gly Sequences Enhance Heparan Sulfate Assembly in Proteoglycans. J. Biol. Chem. 270 (45), 27127-27135. doi:10.1074/jbc.270.45.27127

Zhang, L., Ngo, J. A., Wetzel, M. D., and Marchetti, D. (2015). Heparanase Mediates a Novel Mechanism in Lapatinib-Resistant Brain Metastatic Breast Cancer. Neoplasia 17 (1), 101-113. doi:10.1016/j.neo.2014.11.007

Zhao, X., Li, M., Dai, X., Yang, Y., Peng, Y., Xu, C., et al. (2020). Downregulation of Exosomal miR-1273a I-ncreases C-isplatin R-esistance of N-on-small C-ell L-ung C-ancer by U-pregulating the E-xpression of S-yndecan B-inding P-rotein. Oncol. Rep. 44 (5), 2165-2173. doi:10.3892/or.2020.7753
Zhou, H., Roy, S., Cochran, E., Zouaoui, R., Chu, C. L., Duffner, J., et al. (2011). M402, a Novel Heparan Sulfate Mimetic, Targets Multiple Pathways Implicated in Tumor Progression and Metastasis. PLoS One 6 (6), e21106. doi:10.1371/ journal.pone.0021106

Zong, F., Fthenou, E., Castro, J., Pã@terfia, B., Kovalszky, I., Szil Ãjk, L., et al. (2010). Effect of Syndecan-1 Overexpression on Mesenchymal Tumour Cell Proliferation with Focus on Different Functional Domains. Cell Prolif 43 (1), 29-40. doi:10.1111/j.1365-2184.2009.00651.x

Zong, F., Fthenou, E., Mundt, F., Szatmári, T., Kovalszky, I., Szilák, L., et al. (2011). Specific Syndecan-1 Domains Regulate Mesenchymal Tumor Cell Adhesion, Motility and Migration. PLoS One 6 (6), e14816. doi:10.1371/ journal.pone.0014816

Zong, F., Fthenou, E., Wolmer, N., Hollósi, P., Kovalszky, I., Szilák, L., et al. (2009). Syndecan-1 and FGF-2, but Not FGF Receptor-1, Share a Common Transport Route and Co-localize with Heparanase in the Nuclei of Mesenchymal Tumor Cells. PLoS One 4 (10), e7346. doi:10.1371/journal.pone.0007346

Conflict of Interest: The authors declare that the research was conducted in the absence of any commercial or financial relationships that could be construed as a potential conflict of interest.

Publisher's Note: All claims expressed in this article are solely those of the authors and do not necessarily represent those of their affiliated organizations, or those of the publisher, the editors and the reviewers. Any product that may be evaluated in this article, or claim that may be made by its manufacturer, is not guaranteed or endorsed by the publisher.

Copyright (c) 2022 Guo, Wu, Lei, Zhong, Wang, Zhang, Zhao, Huang, Shi and Wu. This is an open-access article distributed under the terms of the Creative Commons Attribution License (CC BY). The use, distribution or reproduction in other forums is permitted, provided the original author(s) and the copyright owner(s) are credited and that the original publication in this journal is cited, in accordance with accepted academic practice. No use, distribution or reproduction is permitted which does not comply with these terms. 